\title{
THE BALKAN POLITICAL AREA: PROSPECTS FOR A RENEWED INTEGRATION OF THE EUROPEAN UNION
}

The contribution briefly analyses the methods and criteria for accession of a state to the European Union and investigates the accession process of the Western Balkans states. The contribution intends to underline the strategic importance of the states of the Balkan Region for the purpose of relaunching the process of European integration.

KEY WORDS: Balkan Region, accession to the EU, European integration, democracy.

\section{INTRODUCTORY REMARKS}

As it is well known, the European Union is an international organization open to the accession $^{66}$ of new states which, from the original six member states, has registered an ever-increasing number of accessions.

In particular, the enlargement of the European Union to the East for a variety of reasons has given rise to different points of view between those for and against; between those who considered the opening of the EU to the countries of the Balkan Region as a duty and those who, on the contrary, considered it a hasty and instrumental act to the interests of some Western European member states.

Whatever the position one wants to take, the fact remains that the Balkan region, despite all its contradictions and its various political and social traditions, represents an interesting political space that can constitute an important perspective for the relaunch of the process of European integration.

Undoubtedly, the fragility of the economic and social systems of some of the countries of the Balkan region and the reaction of some of them to the problems deriving from

\footnotetext{
* PhD, Full Professor of European Union Law, University “Kore” of Enna. Email: annavalvo@virgilio.it.

${ }^{66}$ In reality, it is a real admission procedure which, as evident, requires the accord the state requesting to be admitted and of the international organization accepting the request. On the contrary, the accession procedure concretizes the participation of the state, precisely, with the simple accession without the states which are already members being able to plead anything in relation to the new participant in the international organization.
} 
mass immigration and the deportation policy carried out by some member states of the European Union is a problem that must be tackled from an integrationist point of view and not, as it has been until now, in terms of almost ghettoization of these states. The great opportunity that the enlargement to the East represents for the process of European integration remains a fact.

In this context, particular attention should be paid to the so-called "Visegrád Group", the political cooperation agreement that brings together Poland, Hungary, the Czech Republic and Slovakia ${ }^{67}$, acting as a barrier not only to uncontrolled immigration ${ }^{68}$ but also to hyper-liberal economic policies.

\section{THE EU ACCESSION PROCEDURE}

The procedure for the accession of new member States is governed by Article 49 of the TEU. This is an apparently simple procedure which in reality involves a complex system of bilateral negotiations conducted by the Commission and by the State that has applied for membership ${ }^{69}$.

European States ${ }^{70}$ can apply for EU membership by addressing the request to the Council, which decides unanimously after consulting the Commission and after approval by the European Parliament.

Not only the European Parliament but also the national parliaments must be informed of the application for the membership, in compliance with the new role assigned to them by the Lisbon Treaty.

${ }^{67}$ As is known, the so-called "Visegrád Group" is a political cooperation agreement dating back to February 1991 concluded between Poland, Czechoslovakia and Hungary, close to the fall of the Soviet Union. Initially known as the "Visegrád Triangle", the group changed its name in 1993 following the division of Czechoslovakia into the Czech Republic and Slovakia.

${ }^{68}$ Some states of the Balkan region have been hit by the wave of migration along the so-called "Balkan route". On the other hand, the negative attitude of these states towards the reception and inclusion of migrants is shared by the latter who consider the Balkans a sort of "transit land" towards richer and more developed Central and Northern European states.

${ }^{69}$ After having acquired the status of candidate country, accession negotiations are started. There are thirty-five chapters relating to the negotiation procedure. Before its launch, the Commission publishes a report for each chapter recommending the start of negotiations for the chapter in question or setting parameters that must be respected by the candidate country. When the progress made by the state towards accession is considered satisfactory, the Commission can recommend "provisionally closing" the negotiating chapter. The Council again decides unanimously. When the negotiations of all chapters are completed, the general conditions - including any safeguard clauses and transitional provisions - are inserted in an accession treaty between the member states of the European Union and the candidate state. When the negotiations of all chapters are completed, the general conditions - including any safeguard clauses and transitional provisions - are inserted in an accession treaty between the member states of the European Union and the candidate state. See: BENEDETTI, La crisi del processo d'integrazione europea tra ammissione e recesso. Le sfide e le opportunità dellallargamento ai Balcani occidentali e della Brexit, Roma, 2017.

${ }^{70}$ As for the geographical requirement, it should be noted that due to the indefinability of the borders of Europe, this is a criterion that was used on the basis of certain data only on the occasion of the rejection of Morocco's application for membership in 1987. In this regard, there are those who argue that the geographical borders of Europe are more than anything else the result of a sum of historical and psychological elements. See: Mikkeli, Europa: storia di un'idea e di un'identità, Bologna, 2002, p. 24 ss. 
The application must come from the state that intends to join which must meet two requirements: a) a requirement of a geographical nature that the state must belong to Europe and b) a requirement of a political nature that the state must respect and promote the values referred to in Article 2 TEU on which the European Union is founded, namely the respect for human dignity, freedom, democracy, equality, the rule of law and human rights including the rights of minorities.

The accession of a new member state requires a unanimous decision by the Council and therefore, essentially, the approval of all member states.

The Council acts unanimously after consulting the Commission and after obtaining the consent of the European Parliament, which decides by a majority of its members.

The state thus acquires the status of candidate country for accession.

It should be noted that the obligation to consult the Commission does not bind the Council which, obliged exclusively to obtain the opinion of the Commission, can, however, also ignore it and decide in a different way.

On the contrary, the approval of the Parliament binds the Council which, in the event of non-approval by the Parliament, cannot decide on the admission of a new members State.

As for the "eligibility criteria agreed by the European Council", these are the criteria established at the Copenhagen European Council of 21-22 June 1993 where three categories of criteria were identified: 1 ) a legal criterion relating to the adaptation of the candidate state to the Treaties and the EU acquis; 2) a political criterion relating to the institutional stability of the candidate state which must guarantee democracy, the rule of law, human rights and the protection of minorities; in essence, the compliance with the values referred to in Article 2 TEU (formerly Article 6); 3) an economic criterion relating to the existence of an open market economy in a regime of free competition ${ }^{71}$.

The accession procedure ends with the stipulation of an international agreement between the already member states and the acceding state which in an annexed document contains the conditions of admission and the adjustments made necessary by the new entry or entries.

The effective entry of the new member state (or states) will take place after the conclusion of the ratification procedures by all member states and the entry into force of the accession agreement $^{72}$.

Following the withdrawal of the United Kingdom, the European Union currently has 27 member states ${ }^{73}$.

\footnotetext{
${ }^{71}$ These criteria were identified precisely in function of the accession of the Eastern European states. It is no coincidence, in fact, that the political criteria specifically concern the presence of democratic institutions that guarantee the rule of law and a democratic order based on parliamentary representation, respect for fundamental rights and freedoms and respect for minorities. See, about it, in: SchimmELFENning-Sedelmeier (eds.), The politics of European Union Enlargement: Theoretical Approaches, London- New York, 2005.

${ }^{72}$ The accession procedure to become a member state to the European Union (as well as the withdrawal procedure), highlights the typically international profile of the EU, its lack of originality and its intimate link with the member states that determined its birth and determine its permanent existence.

${ }^{73}$ Compared to the original nucleus of the six founding states, the accession of the other member states took place in the following moments: 1 January 1973 - United Kingdom, Ireland and Denmark; 1 January 1981 - Greece; 10 January - 1986 Spain and Portugal; 1 January 1995 - Austria, Finland and Sweden; 1 May 2004 - Cyprus, Estonia, Lithuania, Latvia, Malta, Poland, Slovakia, Slovenia, the Czech Republic and Hungary; 1 January 2007 - Bulgaria and Romania; 1 July 2013 - Croatia.
} 


\section{THE ENLARGEMENT OF THE EUROPEAN UNION AS A POLITICAL PROCESS}

Undoubtedly, the enlargement of the European Union and the accession of new member states can be considered a political process that takes place within a specific legal framework.

It is clear that the member states of the European Union have always considered enlargement as an instrument of political stability as well as of promotion (at least until a given moment) of the economic prosperity of its member states ${ }^{74}$.

It is hardly necessary to recall that despite the important role played by the Commission, the accession process is a typically intergovernmental process that requires the unanimity of the Council and the ratification of the accession agreement by all states. And from this specific point of view, it is clear that the accession of a new state is conditioned more by political considerations and dynamics, which can influence and determine the outcome, than by strictly legal criteria.

If well managed, the enlargement process is the most important integration tool available to the European Union which, beyond the criticisms that can be made of its current political and economic situation, has contributed to a large extent to the functioning of democracies, respect for fundamental rights and freedoms and the rule of law in many European States (including those of the East) guaranteeing peace, security and political and economic stability.

In this sense, although it must be recognized that the hasty enlargement of 2004 contributed in no small measure to the current state of crisis of the European Union, affecting the ability of its institutions to function properly in the complicated political framework of the plurality of its states, there is no doubt that the opening towards the Balkan region and the conclusion of the accession process of the already candidate states can stimulate the resumption of the political integration process.

Currently the candidate countries for accession are Turkey, North Macedonia, Albania, Serbia, Montenegro and Iceland which, despite not having withdrawn the application for membership, in 2015 asked the European Union not to consider it anymore as a candidate country. Potential candidate states are Bosnia and Herzegovina and Kosovo.

On 30 September 2018 in the former Yugoslav Republic of Macedonia, the consultative referendum on changing the name of this small state, demanded by Greece as a condition for its accession to the European Union, failed (due to failure to reach a quorum). On October 19, the Parliament of the former Yugoslav Republic of Macedonia, albeit by a narrow margin, had approved the amendment to the Constitution to change the name of the country to the Republic of North Macedonia. At the beginning of January 2019, the parliamentary procedure was launched which definitively approved the constitutional amendment relating to the change of name as requested by Greece. At the end of January, the Greek Parliament also approved the relative agreement between the Greek Premier and the North Macedonian Premier and, at least from this specific point of view, one of

\footnotetext{
${ }^{74}$ Instability in the Balkan region is a problem in Europe and history has shown that the integration of the Western Balkans has been the primary means of ensuring security, stability and democracy.
} 
the obstacles to the accession of the Republic of North Macedonia to the European Union has been overcome ${ }^{75}$.

\section{THE STATE OF THE ART OF THE ACCESSION PROCESS OF THE STATES OF THE BALKAN REGION}

More than a legal process, the enlargement process can be considered a process influenced by political logic and calculations that leaves to the states which are already members a wide margin of discretion on whether or not to admit a state that has applied for membership (or admission) and the European Union reserves the right to decide when a state is ready to start the accession process.

As for the states of the Balkan region, the beginning of the negotiations and, therefore, the accession process was preceded by a Stabilization and Association Agreement that the Treaty (art. 217 TFEU) defines as an association involving reciprocal rights and obligations, joint actions and particular procedures, relating to political, economic, commercial and human rights issues. In other words, the association agreements define the legal basis on future mutual rights and obligations between the parties in view of a possible accession of the state to the European Union ${ }^{76}$.

The gradual fulfilment of the commitments undertaken under the association agreements, as well as the achievement of the objectives set with the Copenhagen criteria, is the main condition for obtaining the necessary technical-financial assistance from the EU by the state that has applied for its membership. At this stage, the European Commission monitors the progress made by the states requesting admission to the European Union.

Once the pre-accession phase is concluded, the procedure is perfected, as mentioned, with the accession treaty.

Currently, the accession and pre-accession situation of the states of the Balkan region is as follows: Albania applied to join the European Union on 28 April 2009.

In 2012, the Commission showed positive progress and recommended the granting of the candidate status to Albania, subject to the necessary adoption of the reforms not yet implemented. This condition was largely satisfied before the elections held in June 2013 and in October of the same year the Commission recommended the recognition of Albania as a candidate country.

Since June 2014, Albania has acquired the status of candidate country and due to the progress made, the Commission has recommended the opening of accession negotiations with Albania.

\footnotetext{
${ }^{75}$ Since December 2009, citizens of the former Yugoslav Republic of Macedonia (now the Republic of North Macedonia), Montenegro and Serbia have benefited from visa exemption in the Schengen area; this exemption for citizens of Albania and Bosnia and Herzegovina has instead been in force since November 2010. In January 2012, a dialogue with Kosovo on visa liberalization was launched and in July 2018 the Commission confirmed that Kosovo had satisfied the last criterion.

${ }^{76}$ See, in this regard: IngLis, The Europe Agreements Compared in the Light of their Pre-accession Reorientation, in Common Market Law Review, 37, 2000, pp.1173-1189.
} 
In June 2018 the Council had reached the conclusion of a possible opening of accession negotiations with Albania in June 2019; however, the Council did not initiate the opening of accession negotiations and only in March 2020 the Council, in its "General Affairs" composition, decided to start the accession negotiations with the Republic of Albania.

Bosnia and Herzegovina is a potential candidate country. Its application for membership was submitted on 15 February 2016 and the Commission published its opinion in May 2019, including a list of 14 key priorities.

The former Yugoslav Republic of Macedonia (now the Republic of North Macedonia) applied to join the European Union in March 2004 and was granted candidate country status in December 2005.

Since 2009, the Commission, with the support of the Parliament, has recommended the opening of the accession negotiations. However, it was not possible to start accession negotiations mainly due to the dispute with Greece over the country's use of the name "Macedonia". The issue was resolved on the basis of the "Prespa" agreement on the new name "North Macedonia", with effect from February 2019. In March 2020, the Council in its "General Affairs" composition decided to start the accession negotiations with the Republic of North Macedonia ${ }^{77}$.

Kosovo is also a potential candidate country for EU membership. Its future integration into the European Union, as well as that of Serbia, remains linked to the implementation of the EU-facilitated dialogue between Kosovo and Serbia, which should lead to a comprehensive and legally binding agreement on the normalization of their relations.

Montenegro applied to join the EU in December 2008. It was granted the status of candidate country in December 2010 and the accession negotiations began in June 2012.

At the end of 2018, 32 of the total 35 negotiation chapters had been launched, but only five had been provisionally closed. The last remaining key chapter (on competition policy) was not yet open in 2019.

As will be said, in February 2018 the Commission published a new strategy on the Western Balkans where it states that Montenegro (and Serbia) could join the European Union by 2025.

Serbia applied to join the European Union in December 2009 and, in March 2012, when Belgrade and Pristina reached an agreement on the regional representation of Kosovo, it was granted the status of candidate country.

Accession negotiations were formally launched on 21 January 2014. A total of 18 chapters had been launched by the end of 2019 .

With the exception of Croatia which joined the European Union in July 2013, the other Western Balkan states have still made limited progress in the accession process.

Although the European Union since the European Council of Santa Maria de Feira in June 2000 had announced that the countries of the Balkan Region had a good chance of joining the EU, so far, as mentioned, Albania, the Republic of North Macedonia, Serbia and Montenegro are candidate countries while Bosnia and Herzegovina and Kosovo are potential candidate countries. This despite the fact that the European Union has for some

\footnotetext{
${ }^{77}$ See: Friedman, The Name's Macedonia. North Macedonia, in Foreign Affairs, October 2018.
} 
time launched a legal-political framework aimed at guiding these States in the integration process, also defining some principles of political conditionality for the purposes of the Europeanization of an area of particular strategic importance for European political stability.

\section{CONCLUDING CONSIDERATIONS}

In 2017, the then President of the European Commission, Jean Claude Juncker, in his speech on the state of the Union, declared that for the purposes of European stability the Union cannot avoid considering "credible enlargement prospects for the Western Balkans"

For its part, the European Commission has published a communication in which it foresees the accession of new states by $2025,{ }^{79}$ recommending the accession of the countries of the Balkan region in a perspective of greater security for the European Union and guarantees of democracy and respect for human rights by these countries ${ }^{80}$.

However, the Commission did not fail to highlight that, despite the efforts made and the aid received by the European Union, including through the stabilization and association agreements (SAA), the countries of the Western Balkans are recording a serious delay in adapting their legal system to the Copenhagen criteria and therefore to the founding principles of the European Union.

In this context, the countries of the Western Balkans must implement extensive reforms in important areas: the rule of law, fundamental rights and governance must be strengthened. The reforms of the judicial system, the fight against corruption and organized crime, as well as the public administration reform must be translated into tangible results and the functioning of democratic institutions must be seriously strengthened.

These states must also continue along the path of economic reforms and resolve their structural weaknesses, low competitiveness and high unemployment.

Nonetheless, the Commission reaffirms the political-economic interest of the European Union in the incorporation of the Balkan region and underlines how the enlargement policy is part of a broader strategy of strengthening and geostrategic positioning within which the accession of the Western Balkans is essential.

Because of these considerations, the European Union is committed to increasing its support for the transformation process in the Western Balkans, hoping for the conclusion of accession negotiations by 2025 .

\footnotetext{
78 "If we want more stability in our neighbourhood, then we must also maintain a credible enlargement perspective for the Western Balkans. It is clear that there will be no further enlargement during the mandate of this Commission and this Parliament. No candidate is ready. But thereafter the European Union will be greater than 27 in number. Accession candidates must give the rule of law, justice and fundamental rights utmost priority in the negotiations".

${ }^{79}$ Communication from the Commission to the European Parliament, the Council, the European Economic and Social Committee and the Committee of the Regions - A credible enlargement perspective for and enhanced EU engagement with the Western Balkans, Сом(208) 65 final, 6 February 2018.

${ }^{80}$ See: Rosanò, Fra ipocrisia organizzata e allargamento strategico: l'Unione europea, i Balcani occidentali e alcune prospettive di crisi dello stato di diritto, in federalismi.it, September, 2019.
} 


\section{LIST OF REFERENCES}

Benedetti, La crisi del processo d'integrazione europea tra ammissione e recesso. Le sfide e le opportunità dell'allargamento ai Balcani occidentali e della Brexit, Roma, 2017.

Communication from the Commission to the European Parliament, the Council, the European Economic and Social Committee and the Committee of the Regions - A credible enlargement perspective for and enhanced EU engagement with the Western Balkans, сом(208) 65 final, 6 February 2018.

Friedman, The Name's Macedonia. North Macedonia, in Foreign Affairs, October 2018.

IngLIs, The Europe Agreements Compared in the Light of their Pre-accession Reorientation, in Common Market Law Review, 37, 2000, pp.1173-1189.

Miккeli, Europa: storia di un'idea e di un'identità, Bologna, 2002.

Rosanò, Fra ipocrisia organizzata e allargamento strategico: l'Unione europea, i Balcani occidentali e alcune prospettive di crisi dello stato di diritto, in federalismi.it, September, 2019.

Schimmelfenning-Sedelmeier (eds.), The politics of European Union Enlargement: Theoretical Approaches, London- New York, 2005. 